\title{
AFGHANISTAN IN THE IMMEDIATE POST-TRAUMA CASE: INVESTIGATING POLITICAL DEVELOPMENTS IN THE YEARS (2002-2008)
}

\author{
Muhammad Dawood Kakar \\ PhD scholar SPIR, \\ Quaid-I- Azam University \\ Islamabad-Pakistan \\ Daudkakar17@gmail.com \\ Dr. Samra Naz, \\ Assistant Professor \\ Department of Humanities and Social Sciences \\ Bahria University Islamabad Campus \\ Samra.buic@bahria.edu.pk \\ Ali Raza Momand \\ Lecturer in Political Science \\ Higher Education Department \\ KPK-Pakistan \\ lectureralimmd@gmail.com
}

\section{Abstract}

Afghanistan has been ruled under informal arrangements of power for most of its life. Due to conventional politics, political institutions have been less prioritized over time. Historically, Afghanistan has been short of a sound and secured political environment owing to multitudes of problems: geostrategic location, ethnic disorder, the conservative-liberal ideological gap, the sectarian divide, its tribal structure, etc. Afghan code of political conduct is based on longstanding traditions under which matters of local and even national importance are settled by the Jirga (local council) following those rules. The Head of a tribe is always cherished and his words carry weight. The Jirga system still prevails in Afghanistan and the Pashtun belt of Pakistan. Despite being an archaic scheme, the Jirga system has its merits in Afghan's social and political lives as it decides their day-to-day matters within due space of time, and its assessments are valued because of the tribal social code. In the current 


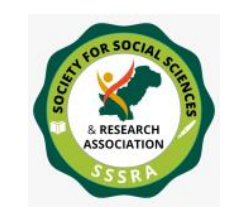

Pak. Journal of Int'L Affairs, Vol 4, Issue 1 (2021) $\quad$ Afghanistan In The Immediate Post-Trauma ...

political developments following the Bonn Agreement, 2001, the informal provisions of power have been given a legal role as the Loya Jirga approved the Constitution and played an active part in the Interim and Transitional Afghan setups. This research paper presents a short history of power patterns in Afghanistan and studies its current political system at national and sub-national levels.

\section{A Short History of the Power Patterns in Afghanistan}

Afghanistan is a traditional society with multi-ethnic tribal composition. Pashtun, Tajik, Uzbek, Hazara, and several small tribes constitute the ethnic configuration of Afghanistan. The tribes have chiefs and under the customary rules the chiefs are respected and their orders obeyed. In cases of land distribution, marriage settlement, war and peace, conflict resolution, and intra and inter-tribal relations of any kind and shape, the elders get together and try to arrive at some agreed measures to that effect. Hence, for a greater part of Afghans' political lives, Afghanistan has been ruled under these traditional-cum-informal schemes of power. Afghanistan emerged as an autonomous political entity in the year 1747, when Ahmad Khan Abdali declared a (Pashtun) Tribal Confederation in Afghanistan. The frontiers of that Confederation were extended from Central Asia and Kashmir to the Arabian Sea and from Persia to the Indian Punjab. However, in strict terms, it was more of an alliance of the Pashtun tribes than a State (Choudary, 2004).

Serious efforts aimed at effective state-building in Afghanistan were initiated by Amir Abdur Rehman 'the Iron Amir' who established a centralized state in 1880 by dismantling the tribal system and bringing the scattered tribes under the rule of the same law with brutal use of force in cases of any deviation on the part of them (Dupree, 1984). To hold the tribes under his control, he ordered a re-settlement of their boundaries and realized a sub-division of major provinces into districts and sub-districts. He organized a harsh police force to deal with suspected opponents. The thing that troubled him in effectuating his political agenda was the lack of financial resources and for that matter, he had to rely on British assistance. Abdur Rehman Khan, to legitimize his throne under Islamic dicta, titled himself as Imam of the Afghans. He established an elitist bureaucracy on Ottoman pattern; made it, as delinked from their respective ethnic bases, responsible solely to him (Choudary, 2004).

Amir Abdur Rehman was succeeded by his son Habibullah who struggled to get Afghanistan free from British India's political sway. He strived for gaining a sovereign status for Afghanistan which the British denied to award him during his lifetime. He was 


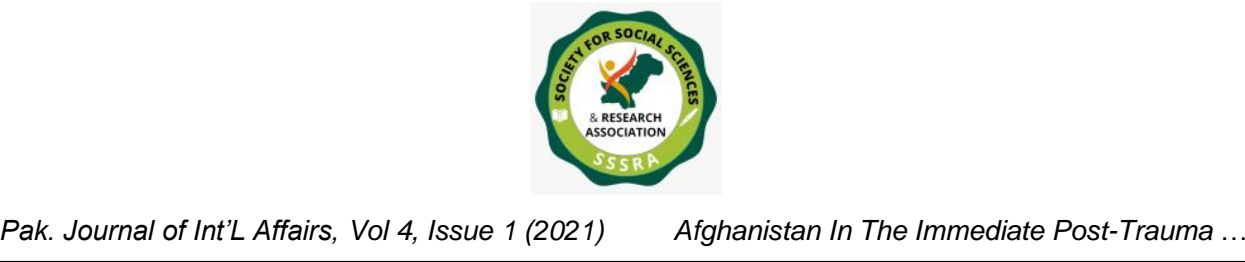

assassinated in 1919 and was succeeded by his son Amanullah who moved for swift changes in the sociopolitical life of the state (Choudary, 2004). After the Third AngloAfghan War of May 1919, Amanullah earned for Afghanistan its independence and sovereign status and got Afghanistan free from British control by $19^{\text {th }}$ of August 1919, under the Treaty of Rawalpindi. In 1923, inspired by Mustafa Kemal Ataturk, he gave Afghanistan its first modern Constitution based on secular principles. He titled himself as the King and declared his office a hereditary one. His liberal approach towards women's rights in a conservative Afghanistan stirred a great resentment amongst the people which eventually caused his removal from office (Choudary, 2004).

King Zahir Shah brought Afghanistan back to order after Amanullah's tragic demise. His era (1933-1973) is regarded by the older Afghans as a glorious period as Afghanistan saw its national legislature established, had a Constitution (1964) wherein women's rights were ensured (Katzman, 2010, September). However, Zahir Shah's rule over mainland Afghanistan weakened as time passed by and virtually got confined to the capital city of Kabul. Consequently, his son-in-law Sardar Muhammad Daud removed him from office through a coup backed up by left-wing military officers.

Sooner the communists felt betrayed by Daud and they, through a bloody attack on the Presidential palace, killed him along with his family in December 1978. With the PDPA (Peoples Democratic Party of Afghanistan) in power, nationalization of the economy and other state departments commenced. A society, habitual with traditional order for so long, could not be made ready for changes of the kind so quickly. Consequently, the state went into law and order crises. When crises went out of the hands of the ruling PDPA, the Soviet Union had to come up for supporting the waning PDPA government in late 1979. The Soviet meddling in Afghan affairs was felt as a threat by the Islamists inland and the neighboring states of Afghanistan. The Islamists started a guerilla war against the communist regime and the Soviet forces in Afghanistan who were backed by several regional and global powers. Eventually, the Islamists stood victorious and the Soviet forces had to leave Afghanistan in 1991. The tumultuous decade of the 1980s put the already fragile State structure of Afghanistan in a pathetic condition. In the immediate post-Soviet withdrawal era, civil war erupted among various Islamic militant groups. The civil war ended with a victory for the madrassa students (the Taliban), under the leadership of Mullah Umer in 1996. They ensured somehow a secured environment for a shorter period solely due to the brutal use of force but their strict fundamentalist public policies were widely criticized by the world community. Following the event of 9/11 and the subsequent international involvement in Afghan affairs, after the overthrow of the Taliban, Afghanistan has seen enormous politico-economic developments. Afghans went 


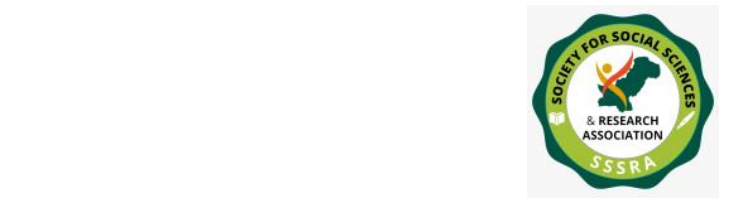

Pak. Journal of Int'L Affairs, Vol 4, Issue 1 (2021)

Afghanistan In The Immediate Post-Trauma ...

out for Presidential and legislative elections for the first time in their political history which is a sign of progress towards the modernization of their politics.

Government at the sub-national level, to an extent, has been created and the Afghans are getting their services with relative ease than before. Despite these developments, the worsening law and order situation undermines every progressive agenda and the presence of war-lords at key posts creates doubts in the minds of the people about the viability of the post-war reconstruction. The paper prefers to explore developments in the legislative sector of the land before throwing light on the executive department.

\section{Legislative Sector of Afghanistan: The Level of Developments}

The parliamentary election in Afghanistan was held in 2005 for both houses of the National Assembly (Afghan Parliament). Afghan National Assembly is bicameral consisting of the Upper House (the Masharano Jirga) and the Lower House (the Wolesi Jirga). The Upper House is an appointed body whereas the lower House has representative nature. The Afghan Parliament (National Assembly) was supposed to act decisively in enhancing democratic culture in Afghanistan as directed under the Bonn process (Ghufran, 2007).

The 2004 Constitution identifies the National Assembly as the highest legislative organ which represents the will of its people. The Wolesi Jirga (the lower House) is specifically tasked to review as well as investigate actions of the Government, besides its role as a legislative body, giving it a primary accountability function. Since its inauguration, the National Assembly has faced the colossal task of reviewing 433 Presidential decrees and pieces of legislation that the Transitional and Interim Authorities of Afghanistan had passed since the dawn of the new era (post-9/11). The new National Assembly also had to review and approve membership of the Cabinet, nine judges in the Supreme Court, and all new pieces of legislation drafted by the Ministry of Justice (Wardak, Saba \& Kazem, 2007).

Voting for the members of the Lower House (Wolesi Jirga) got more media coverage because of its legislative status and direct public participation in it. The upper House, being selected by the President of Afghanistan and the Provincial Councils, was of little currency in the eyes of the media. The bad luck of Afghan legislative composition is its conservative status as most of the ex-Mujahidin have been given extended representation. The War-lords occupy 133 out of 249 seats in the Wolesi Jirga (the lower House- 2005) and 34 out of 102 in the Masharano Jirga (the Upper House-2005). They strictly blocked liberal moves while the Constitution-making process was in operation (Khan, 2006, 


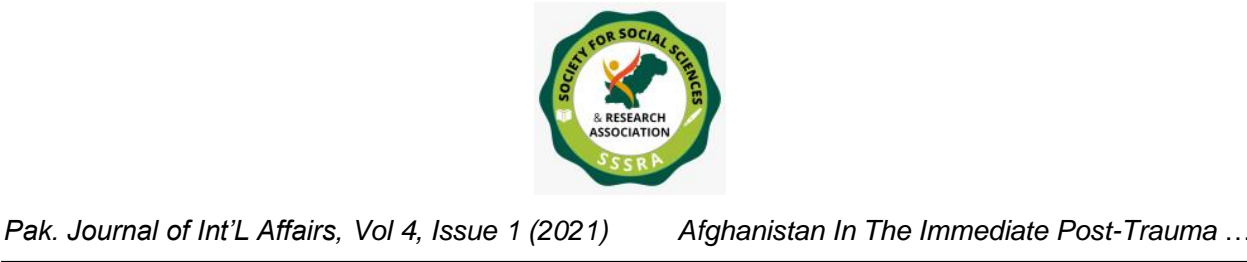

February 27). One of the obstacles that the Parliament has to confront is the lack of professionalism on the part of the Afghan parliamentarians in modern legislative business. Apart from it, the lower House (the Wolesi Jirga) consists of representatives from varied and conflicting ethnic backgrounds posing tough problems to smooth legislative working.

The new Afghan Constitution of 2004 has arranged somewhat a quasi-Presidential set up by giving enormous powers to the President alongside an effective legislature to check his autocratic gestures. The President has been vested with active powers in selecting his cabinet; however Parliamentary approval is necessary to that effect. The Afghan legislature started its early sessions with warm debates on a multitude of issues ranging from traffic barriers to the accountability of an estimated 4000 NGOs working in Afghanistan under the pretext of reconstruction projects. Hamid Karzai, feeling the pressure of the parliament, ordered the Interior Ministry to remove traffic blocks. Apart from it, the legislature also took the issue of a Christian convert, who was permitted, to seek asylum in Italy, by the president. The Assembly criticized the President for letting him free of punishment. The Parliament debated another topic of national importance i.e., the presidential nominees for the cabinet. Five of the proposed twenty-five ministers did not get the required majority of votes and thus the President had to drop them out of the proposed cabinet. Karzai put before the parliament his choice of five other ministers for the dropped ones. The parliament gave assent to his subsequent proposal. This showed the parliament's active role in practicing its constitutional authority as a check on presidential extra-constitutional moves (Ghufran, (2007). Karzai's cabinet could be appreciated for its technocratic composition. Almost half of the ministers were professionals, being Western-educated. The Cabinet to a broader extent had a liberal outlook as only three out of twenty-five Cabinet members were ex-Mujahidin (Ghufran, 2007). However, the Parliament is criticized by the critics on its lack of organizational strength as the 2005 elections were contested on a non-party basis. Lack of organized political force in the form of political parties delays the democratic process as the individual members cannot easily be educated on the points of national policy. Ali A. Jalali in Robert I. Rotberg (Building a New Afghanistan) says, "The 2005 parliamentary elections, held on non-party basis, led to the emergence of a politically weak parliament. Anyhow, the future course of Afghan politics will greatly be seen under the context of executive-legislative relations" (Jalali, 2007).

\section{Groupings within Parliament}

However, groupings did exist in the 2005 elected Parliament. They could broadly be categorized into three groups: - a pro-government bloc of roughly a hundred plus 


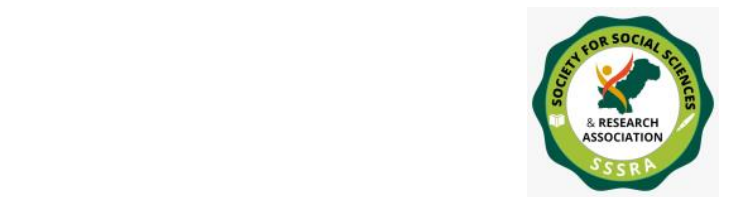

Pak. Journal of Int'L Affairs, Vol 4, Issue 1 (2021)

Afghanistan In The Immediate Post-Trauma ...

members of Parliament included the conservatives (ex-mujahidin) and some liberal members. The opposition bloc consisted of about eighty-plus members. And the third one was a pressure group consisting of around fifty to sixty independent members. The pressure group's inclinations were interest-oriented and by that standard, they could go for supporting either the government or the opposition (Fleschenberg, 2009).

Kenneth Katzman has mentioned that the party presence in Afghan National Assembly was not totally out of existence as Qanooni and Rabbani had organized the opposition bloc into a party in 2007, called the National Front, along with former Communists and some of the members of the royal family. He writes, "In April 2007, Qanooni and Northern Alliance political leader Rabbani organized this opposition block, along with ex-Communists and some royal-family members, into a party called the National Front that wanted increased parliamentary powers and direct elections for the provincial governors" (Katzman, 2009, June).

The National Front was in strong opposition to President Karzai in the Lower House of the National Assembly (Afghan Parliament). Katzman supports the argument by saying that, "The National Front and Hamid Karzai have a continuous fight to get the support of the many independent parliamentarians in the Wolesi Jirga. Several outspoken women and intellectuals constitute the independent class of parliamentarians, including 32-yearold Malalay Joya (Farah province), a vigilant women's rights supporter and hard-line critic of War-lords. Others are Ms. Fauzia Gailani (Herat province); Ms. Shukria Barekzai, editor of Women Mirror Magazine; and Mr. Ramazan Bashardost, a former Karzai minister who champions Parliamentary powers" (Katzman, 2009, June). To confront the National Front Karzai had intended to form a party of his like-minded members of the National Assembly. As Katzman points out that Karzai has decided to form a party, his likeminded groups in the Wolesi Jirga comprises about 40 ex-members of the conservative Pashtun-based Hizb-e-Islam party; 59 members of Abd-i-Rab Rasul Sayyaf, a famous Islamic conservative mujahedin party leader who was defeated for the speakership; several Karzai clan members including elder brother Qayyum and cousin Jamil Karzai (Qandahar province) and relative, Aref Nurzai. Also among pro-Karzai are former war-lords and Taliban commanders, including Hazrat Ali (Nangarhar province), who gained fame for engineering the Afghan attack on the Al Qaeda hideouts at Tora Bora during the U.S.-led war; Pacha Khan Zadran, from Paktia province who, by some accounts, helped Osama bin Laden escape Tora Bora; and Mullah Abdul Salam (Mullah Rocketi), from Zabol province (Katzman, 2009, June).

\section{Afghan Political System and the Challenges Ahead}




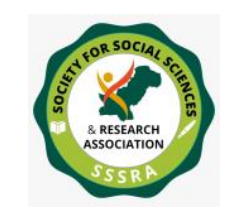

Pak. Journal of Int'L Affairs, Vol 4, Issue 1 (2021)

Afghanistan In The Immediate Post-Trauma ...

Institution building in the post-conflict case has to be designed in a way to ensure equitable power distribution at various levels; central and sub-national, state-civil society relations and to accommodate different power players within such arrangements (Almond, Strom, \& Dalton, 1974) Political Systems in the post-conflict case are tested based on policymaking and its obvious outputs - that is to deliver in areas such as security, healthcare, education, and state support for disabled and widows and to feel them secured in the polity (Almond, Strom, \& Dalton, 1974). Although political parties and other pressure groups play an important role in giving inputs to the political system to be transformed into state policies, the prime role in policymaking is that of the government through the legislature and permanent civil services (Almond, Strom, \& Dalton, 1974). When political parties are missing, as in the Afghan case, the Parliament has to take extra burden in initiating public policies for legislative proceedings and monitoring its implementation. The legislative organ, in such circumstances, has to promote public interests vis-à-vis the government as the latter's main function would surround legislative initiation and policy enactments. Social cleavages must at all costs be properly handled by the lawmaking organ to leave the law enforcement agencies free to work out their plans. Apart from these points, the central legislature has to be ultra-active in formulating domestic policy mainly focusing on the economic-cum-social sector and foreign policy in how the government should serve state interests in the comity of nations. Afghanistan Human Development Report 2007 depicts the history of the legislature and its lack of authority in legislation amidst monarchical power structures and autocratic statecrafts. The Report runs as; "For most of Afghan's political life, the Afghan legislature has been either absent or dysfunctional in even the most liberal and progressive regimes. Instead, the legislative enactments were mainly driven under the orders of the head of the state or government. Every invasion brought new forms of legal rules and changes to the form of the quasi-legislature. Although Afghanistan's history dates back thousands of years, its formal legal institutions are less than 150 years old and were never allowed to evolve. What has been consistent is the struggle to find a balance between positive law and the various schools of Islamic law" (Wardak, Saba \& Kazem, 2007). Thus replacing the centuries-old traditional patterns of law-making, law-enforcing and law-adjudicating could be a litmus test for the nascent post-Bonn Afghan political system. Afghans are habitual with the informal scheme of governance and any move directed at the introduction of the modern form of legislative business and the subsequent executive enactment might face cumbersome challenges, at least in the shorter run.

\section{Governance at Sub-National Level: A Case Study of the Post-War}

Resettlement of Afghanistan's sub-national sphere continues to be a case study for the post-war development index. Its significance in the progress, stability, and even survival 


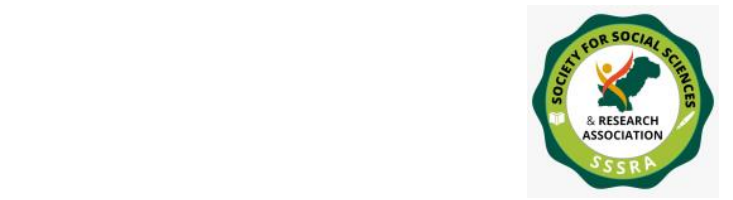

Pak. Journal of Int'L Affairs, Vol 4, Issue 1 (2021)

Afghanistan In The Immediate Post-Trauma ...

of the country's embryonic institutional rebuilding projects cannot be miscalculated. The international society got more interest in this arena during 2005-6 and several steps were taken in this regard. To quote a few, Representative Provincial Councils (RPCs) were established along with Provincial Development Committees (PDCs); some provinces and districts got the benefits of public administrative reforms, and the National Solidarity Program (NSP) got extended communitywide (Nixon, 2008). Governance at a broader level can be defined as "the process whereby societies or organizations make important decisions, determine whom they involve and how they render an account" (Plumptre, \& Graham, 1999). The governance needs to have a presence at broader levels of a nation. In today's politically advanced nations, the concept of decentralization of powers and resources has got immense importance. The best practice, in so for the post-war recovery is concerned, needs, among other essentials, the distribution of powers between the center and local administrative units. "It is an agreed principle among the international community that decentralization suits the Afghan case from various angles. Administrative efficiency can be enhanced by delivering public goods at the sub-national level. Decentralization can be political (decision-making), administrative (service delivery), and fiscal (resource allocation). It can also take different forms: in decentralization, responsibility and resources are moved to local levels while accountability rests with the center; devolution involves the transfer of authority to subnational units with some autonomy (e.g. in federal systems), and delegation involves the allocation of functions outside state structures (e.g. NGOs and Quangos)" (Lister, 2005). However, looking at the Afghan political history, it is quite clear that owing to several factors like warlordism, ethnic divides, linguistic issues, ideological and sectarian rifts, the decentralization of powers, or in other words the federal solution to the Afghan problem may not be a good option. It has been seen in the past that an effective centralized Afghan state has remained more secured than a decentralized regime. "In Afghanistan, the success of a decentralized polity needs governance prevalence at all levels of the polity before going to a gradual process of devolution of powers. Not backed by an Afghan capacity to administer their respective domains as required by the successful decentralization process, the policy may not meet its desired ends" (Stallard, 2003). "Moreover, in Afghanistan, there is a considerable desire on the part of both government and citizenry for strong centralization, in part because of historical legacies of fragmented power and fear of further fragmentation, and in part the result of centralized state structures that were not destroyed by conflict" (The World Bank, 2004). Governance Institutions in today's Afghanistan, however, at sub-national could be characterized by the lack of presence at sub-national or devolution of power policies. Afghanistan has historically been governed under centralized governance patterns, thus introducing the devolution of power plan need to be taken with proper care and effective policy mechanism. The centralization of power was thought to safeguard the state from 


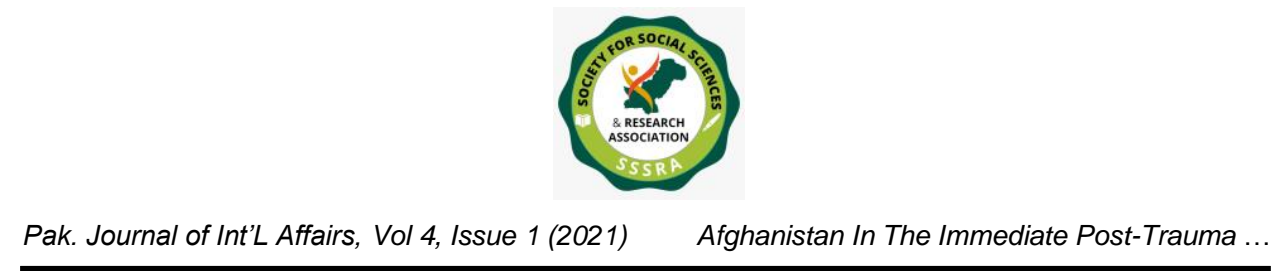

fragmentation and further destabilization during various stages of political development. Keeping in view the role of warlords, devolution at the time of chaos could only mean the disintegration of the State. Before going to introduce decentralization of power, state structure must first be made responsive and operational at all levels of powers to meet any possible upheaval.

\section{Conclusion}

Afghanistan for a shorter course of its life has been governed in modern terms partly because of the traditional structure of its society and partly owing to the prevailing war scenario. Traditionalist-Modernist divide on one hand and ethnic clashes on the other has proved to be the hard venture to take on in the direction of long-lasting political developments. The perennial wars, external aggressions, and internal clashes among the power seeker elites have been a headache for the survival and operational capabilities of the state institutions. In the post-Bonn reconstruction, aimed at institutional development, Afghanistan has observed some novel happenings like elections for the national legislature, direct elections for the President, Judicial restructuring, the organization of armed force and national police, etc. Governance has reached the sub-national level, though with minimal intensity. Institution building in the administrative sphere is welcoming news for the Afghans but that needs more labor to be fully responsive and active. The presidential office has been made powerful along with a strong legislature to check his extra-constitutional gestures. Despite these developments, the core issues still need to be resolved. War-lordism continues to impede the way of modernization of State institutions. Poppy cultivation and the resurgence of violence are in their high times. Unless the illegal business products are not controlled the State would continue its downfall. 
Afghanistan In The Immediate Post-Trauma ...

\section{References}

Almond, G. A., Strom, K., \& Dalton, R. J. (1974). Comparative Politics Today: A World View. G. B. Powell (Ed.). Little, Brown.

Choudary, M. (2004). Afghanistan: a Modern History, Monarchy, Despotism or Democracy, the Problem of Governance in the Muslim Tradition; Angelo Rasanayagam.

Dupree, L. (1984). Afghanistan in 1983: and still no solution.Asian Survey, 24(2), 229-239.

Englehart, N. (2010). A Tale of Two Afghanistan's: Comparative Governance and Insurgency in the North and South. Asian Survey, 50(4), 735-758. doi:10.1525/as.2010.50.4.735

Fleschenberg, A. (2009). Afghanistan's parliament in the making. Gendered Understandings and Practices of Politics in a Transitional Country, Berlin: Heinrich-BöllFoundation/UNIFEM.

Ghufran, N. (2007). Afghanistan in 2006: The complications of post-conflict transition. Asian Survey,47(1), 87-98.

Jalali, A. A. (2007). The legacy of war and the challenge of peace building. In Building a new Afghanistan, edited by Robert I. Rotberg, Lahore: Vanguard Books, 22-55.

Katzman, K. (2009, June). Afghanistan: government formation and performance. Library Of Congress Washington DC Congressional Research Service. CRS.

Katzman, K. (2010, September). Afghanistan: Post-Taliban governance, security, and US policy. Library Of Congress Washington DC Congressional Research Service.

Khan, T. A. (2006, February 27). Afghan War: The Way Out, Dawn Opinion. https://www.dawn.com/news/1068781.

Lister, S. (2005). Caught in Confusion: Local Governance Structures in Afghanistan. Universitäts-und Landesbibliothek Sachsen-Anhalt.

Nixon, H. (2008). Subnational State-Building in Afghanistan. Kabul: Afghanistan Research

Plumptre, T. W., \& Graham, J. (1999). Governance and good governance: international and aboriginal perspectives. 
Stallard, D. (2003). Speaking Out: Afghan Opinions on Rights and Responsibilities. Human Rights Research and Advocacy Consortium.

The World Bank, (2004). Afghanistan: State Building, Sustaining Growth, and Reducing Poverty, Washington, DC: World Bank.

Wardak, A., Saba, D., \& Kazem, H. (2007). Afghanistan Human Development Report: Bridging Modernity and Tradition: Rule of Law and the Search for Justice. Kabul: Center for Policy and Human Development. 